\title{
Enzymes Involved in Wall Peptide Crosslinking in Escherichia coli K12, Strain 44
}

\author{
Martine Nguyen-Distìche, Jean-Marie Ghuysen, Jerry J. Pollock, Peter ReYnolds, \\ Harold R. Perkins, Jacques Coyette, and Milton R. J. Salton \\ Service de Microbiologie, Faculté de Médecine, Institut de Botanique, Université de Liège, \\ Department of Microbiology, New York University School of Medicine, New York, Department of Biochemistry, \\ Sub-Department of Chemical Microbiology, University of Cambridge, and National Institute for Medical Research, London
}

(Received August 10, 1973)

By using the glutamate-amidated tetrapeptide L-alanyl-D-isoglutaminyl-(L)-meso-diaminopimelyl-(L)-D-alanine as a probe, there appears to exist in the membranes of Escherichia coli $\mathrm{K} 12$ strain 44 a DD-carboxypeptidase-endopeptidase system which does not recognize this peptide and a DD-carboxypeptidase-transpeptidase system which recognizes it. The DD-carboxypeptidaseendopeptidase system is essentially hydrolytic. It catalyzes the hydrolysis of UDP- $N$-acetylmuramyl-pentapeptide into UDP- $N$-acetylmuramyl-tetrapeptide and the hydrolysis of the wall peptidoglycan peptide dimer into monomers. These activities are not inhibited by the glutamateamidated tetrapeptide. The system may consist either of two enzyme proteins having predominantly carboxypeptidase activity and endopeptidase activity, respectively, or of one enzyme protein of which the functioning would depend upon the environmental conditions. The DD-carboxypeptidase-transpeptidase system (a) catalyzes concomitant hydrolysis (carboxypeptidase activity) and transfer (natural model transpeptidase activity) reactions with the pentapeptide L-alanyl- $\gamma$-Dglutamyl-(L)-meso-diaminopimelyl-(L)-D-alanyl-D-alanine. The transfer reaction leads to the synthesis of a dimer that is identical to the one which occurs in the $E$. coli wall peptidoglycan; (b) utilizes the glutamate-amidated tetrapeptide as an acceptor. Simultaneous exposure of the pentapeptide and the glutamate-amidated tetrapeptide to the enzyme system leads to the formation of an hybrid monoamidated peptide dimer and causes a decreased hydrolysis of the pentapeptide; (c) by virtue of its own carboxypeptidase activity, it appears to exert some endopeptidase activity. Both carboxypeptidase and endopeptidase activities of this system are inhibited by the glutamate-amidated tetrapeptide, but this represents only a small fraction of the total hydrolytic activity of the membrane Brij-36T extract. (d) The system catalyzes an unnatural model transpeptidation reaction in which glycine replaces $D$-alanine at the C-terminal position of the nucleotide UDP- $N$-acetylmuramyl-pentapeptide. This system may also consist either of two enzyme proteins having predominantly natural model transpeptidase activity and unnatural model transpeptidase activity, respectively, or of one enzyme protein of which the functioning would depend upon the environmental conditions. Whatever the exact situation, the $E$. coli $\mathrm{DD}$-carboxypeptidase-transpeptidase system is in many respects, similar to the DD-carboxypeptidase-transpeptidase single polypeptide enzymes isolated from Streptomyces strains R39 and R61.

Escherichia coli possesses three enzymes activities which are involved in the synthesis and the control of the wall peptidoglycan peptide crosslinking [1-5]. The transpeptidase activity hydrolyzes the C-terminal D-alanyl-D-alanine peptide bond of the pentapeptide sequence L-alanyl- $\gamma$-D-glutamyl-(L)-mesodiaminopimelyl-(L)-D-alanyl-D-alanine with the concomitant transfer of the carboxyl group of the

Abbreviation. Brij-36T, polyoxyethylated $(\bar{n}=10)$ laurylether. penultimate $\mathbf{D}$-alanine residue to the (D)-amino group of the meso-diaminopimelic acid residue of another pentapeptide, leading to the synthesis of C-terminal D-alanyl-(D)-meso-diaminopimelic acid interpeptide bonds. The DD-carboxypeptidase activity hydrolyzes C-terminal D-alanyl-D-alanine peptide bonds without concomitant transpeptidation thus preventing further propagation of the crosslinking system. The endopeptidase activity [6-7], which is thought to be another manifestation of the DD-carboxypeptidase 
activity [8], solubilizes the intact peptidoglycan by hydrolyzing the interpeptide C-terminal D-alanyl(D)-meso-diaminopimelic acid linkages [9] made by transpeptidation. The membranes isolated from $E$. coli K12 strain 44 were shown to be able to catalyze both the liberation of the C-terminal D-alanine residue from the nucleotide UDP- $N$-acetylmuramylpentapeptide (model carboxypeptidase activity) and the incorporation of $\left[{ }^{14} \mathrm{C}\right] \mathrm{gly}$ cine into the same UDP- $N$-acetylmuramyl-pentapeptide where it replaced the C-terminal D-alanine residue (unnatural model transpeptidase activity) [10]. After extraction of the membranes by Brij-36T, several fractions exhibiting both activities were isolated [10]. The present paper describes experiments which were devised primarily in order to determine whether this unnatural model transpeptidase was able to catalyze the dimerisation of natural pentapeptide units in vitro, i.e. a reaction identical to the one which occurs in vivo during the last stages of the wall peptidoglycan biosynthesis.

\section{MATERIALS AND METHODS}

\section{Membranes and Membrane Fractions}

The following preparations derived from $E$. coli K12 strain 44 [10] were used (Table 1): crude membranes, Brij-36T extracts of the crude membranes, the fraction of the Brij-36T membrane extract unadsorbed on DEAE-cellulose (fraction $\mathrm{A}^{\prime}$ ), the fraction unadsorbed on DEAE-cellulose and ampicillin-affinose (fraction A), the fraction fixed on and eluted from DEAE-cellulose (fraction $B^{\prime}$ ) and the fraction fixed on and eluted from both DEAE-cellulose and ampicillin-affinose 202 (fraction B).

$U D P$-N-Acetylmuramyl-L-alanyl- $\gamma-D$-glutamyl-(L)meso-diaminopimelyl-(L)-D-alanyl-D-alanine and $U D P-\mathrm{N}$-Acetylmuramyl-L-alanyl- $\gamma-D-g l u t a m y l-(L)$ meso-diaminopimelyl-(L)-D-[14C Jalanyl-D-[14C]alanine [10].

These nucleotides were those used previously

Non-amidated Pentapeptide L-Alanyl- $\gamma-D-g l u t a m y l-$ (L)-meso-diaminopimelyl-(L)-D-[14C]alanyl-D-

${ }^{14}$ CJalanine and Glutamate-Amidated Tetrapeptide L-Alanyl-D-isoglutaminyl-(L)-meso-diaminopimelyl(L)-D-alanine

The radioactive non-amidated pentapeptide was prepared by acid hydrolysis of radioactive UDP- $N$ acetylmuramyl-pentapeptide $(5 \mu \mathrm{mol}$ in $1 \mathrm{ml} 0.1 \mathrm{~N}$ $\mathrm{HCl}, 7 \mathrm{~min}$ in a boiling water bath), followed by treatment of the liberated $N$-acetylmuramyl-pentapeptide with the Streptomyces $N$-acetylmuramyl-Lalanine amidase [11]. The non-radioactive glutamate-
Table 1. Fractionation of the membranes of Escherichia col K12, strain 44: flow sheet

For details see [10]

\begin{tabular}{|c|c|}
\hline \multicolumn{2}{|c|}{ Crude membrane } \\
\hline & $\begin{array}{l}\text { Extraction with Brij-36T } \\
\left(\mathrm{NH}_{4}\right)_{2} \mathrm{SO}_{4} \text { precipitation } \\
\text { Chromatography on } \\
\text { DEAE-cellulose }\end{array}$ \\
\hline $\begin{array}{l}\text { Not retained } \\
\text { (Fraction } \mathbf{A}^{\prime} \text { ) }\end{array}$ & $\begin{array}{l}\stackrel{\checkmark}{\text { Retained and eluted }} \\
\text { (Fraction } B^{\prime} \text { ) }\end{array}$ \\
\hline \multicolumn{2}{|c|}{ Filtration on Ampicillin-Affinose } \\
\hline $\begin{array}{l}\text { Not retained } \\
\text { (Fraction A) }\end{array}$ & $\begin{array}{l}\text { Retained and eluted } \\
\text { (Fraction B) }\end{array}$ \\
\hline
\end{tabular}

amidated tetrapeptide was prepared from walls of Streptomyces R39 [12].

${ }^{14}$ C-Labeled Bisdisaccharide Peptide Dimer from E. coli

$E$. coli strain B was grown at $37^{\circ} \mathrm{C}$ in minimal growth medium D [13] on a rotary shaker. After two successive overnight cultures, 1.5-1 flasks containing $200 \mathrm{ml}$ of minimal medium were inoculated $(1 \%$, $\nabla / v)$ and shaken at $37{ }^{\circ} \mathrm{C}$ until the absorbance of the cell suspensions was 0.9 at $550 \mathrm{~nm}$. The cells, collected by centrifugation at room temperature, were suspended in the same volume of fresh, prewarmed medium supplemented with $\mathrm{L}-\left[{ }^{14} \mathrm{C}\right]$ alanine $(50 \mu \mathrm{Ci}$ per flask; specific activity: $156 \mathrm{mCi} / \mathrm{mmol}$; Amersham). After $3 \mathrm{~h}$ at $37^{\circ} \mathrm{C}$ of growth, the cells (stationary phase) were collected by centrifugation at $4^{\circ} \mathrm{C}$, washed once with cold distilled water, disrupted with a Bühler disintegrator (Tübingen, Germany). for 5 min at $4{ }^{\circ} \mathrm{C}$, using $9 \mathrm{~g}$ wet weight of cells, $70 \mathrm{ml}$ glass beads and $30 \mathrm{ml}$ water containing $5 \mathrm{mg}$ DNase. The cell envelopes were collected by centrifugation and the wall peptidoglycan was purified by treatment with hot sodium dodecylsulfate and trypsin, and solubilized by lysozyme as described by Braun and Rehn [14]. The lysozyme-degraded peptidoglycan was filtered in $0.1 \mathrm{M} \mathrm{LiCl}$ on two columns of Sephadex G-50 and Sephadex G-25 connected in series [9], yielding a disaccharide peptide monomer and a bisdisaccharide peptide dimer. Each fraction was desalted by filtration in water on a column of Sephadex G-25. Both monomer and dimer had the same specific activity: 1500 dis. $\times$ min $^{-1} \times$ nmol $^{-1}$ of disaccharide peptide unit.

\section{Enzyme Activities}

The enzyme activities were tested as indicated in Table 2. All the incubations were carried out at 
Table 2. Enzyme activities

$\mathrm{A}_{2} \mathrm{pm}=$ meso-diaminopimelic acid $; \alpha$-Gln $=$ isoglutamine; MurNAc $=N$-acetylmuramic acid; GlcNAc-MurNAc, $=\beta-1,4-N$-acetylglucosaminyl- $N$-acetylmuramic acid

\begin{tabular}{|c|c|c|}
\hline Activity studied & Reaction & Products \\
\hline $\begin{array}{l}\text { 1. DD-Carboxy- } \\
\text { peptidase }\end{array}$ & $\begin{array}{l}\text { UDP-MurNAc-L-Ala- } \gamma \text {-D-Glu-(L)-A } \mathrm{Am} \text {-(L)- } \\
\text { D-Ala-DAla }+\mathrm{H}_{2} \mathrm{O}\end{array}$ & $\begin{array}{l}\text { UDP-MurNAc-tetrapeptide } \\
+ \text { D-Ala }\end{array}$ \\
\hline 2. Endopeptidase & 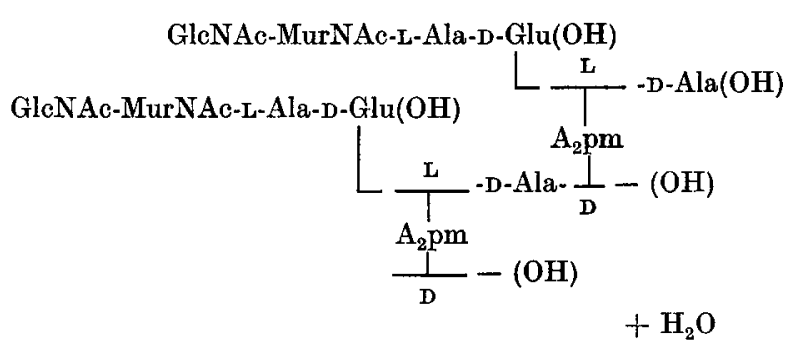 & $\begin{array}{l}\text { GleNAc-MurNAc-L-Ala-D-Glu(OH) } \\
\qquad \frac{\frac{\mathrm{L}}{\mathrm{A}_{2} \mathrm{pm}}}{\mathrm{D}}-\mathrm{D}-\mathrm{Ala}(\mathrm{OH})\end{array}$ \\
\hline $\begin{array}{l}\text { 3. Unnatural model } \\
\text { transpeptidase }\end{array}$ & $\begin{array}{l}\text { UDP-MurNAc-L-Ala- } \gamma \text {-D-Glu-(L)-A2pm-(L)- } \\
\text { D-Ala-D-Ala + Gly }\end{array}$ & $\begin{array}{l}\text { UDP-MurNAc-L-Ala- } \gamma-D-G l u-(L)-A_{2} \text { pm-(L)- } \\
\text { D-Ala-Gly + D-Ala }\end{array}$ \\
\hline $\begin{array}{l}\text { 4. Natural model } \\
\text { transpeptidase } \\
\text { (with concomitant } \\
\text { hydrolysis of } \\
\text { the donor) }\end{array}$ & $\begin{array}{l}\text { L-Ala- } \gamma \text {-D-Glu-(L)- } \mathrm{A}_{2} \mathrm{pm}-(\mathrm{L}) \text {-D-Ala-D-Ala } \\
\text { (acting both as donor and acceptor) } \\
+\mathrm{H}_{2} \mathrm{O}\end{array}$ & $\begin{array}{l}\text { Peptide dimer (no } 9 \text { in Table } 3 \text { ) } \\
+ \text { L-Ala- } \gamma-\mathrm{D}-\mathrm{Glu}-(\mathrm{L})-\mathrm{A}_{2} \mathrm{pm}-(\mathrm{L})-\mathrm{D}-\mathrm{Ala}+\mathrm{D}-\mathrm{Ala}\end{array}$ \\
\hline $\begin{array}{l}\text { 5. Hybrid model } \\
\text { transpeptidase } \\
\text { (with concomitant } \\
\text { hydrolysis of } \\
\text { the donor) }\end{array}$ & $\begin{array}{l}\text { L-Ala- } \gamma-D-G l u-(L)-A_{2} p m-(L)-D-A l a-D-A l a- \\
+\mathrm{L}-A l a-D-\alpha-G \ln -(\mathrm{L})-\mathrm{A}_{2} \mathrm{pm}-(\mathrm{L}) \cdot \mathrm{D}-\mathrm{Ala} \\
+\mathrm{H}_{2} \mathrm{O}\end{array}$ & $\begin{array}{l}\text { Peptide dimer (no } 9 \text { in Table } 3 \text { ) } \\
+ \text { Peptide dimer (no } 10 \text { in Table } 3 \text { ) } \\
+ \text { L-Ala- } \gamma-D-G l u-(L)-A_{2} \text { pm-(L)-D-Ala }+ \text { D-Ala }\end{array}$ \\
\hline
\end{tabular}

$37^{\circ} \mathrm{C}$ in $0.06 \mathrm{M}$ Tris-HCl buffer $\mathrm{pH} 8.5$ containing $0.05 \mathrm{M} \mathrm{MgCl}_{2}, 0.14 \mathrm{mM}$ dithiothreitol and $0.36 \%$ to $8 \%(w / \nabla)$ Brij-36T. The products of the reactions were separated by electrophoresis on Whatman $3 \mathrm{MM}$ paper at $60 \mathrm{~V} / \mathrm{cm}$, with a Gilson High Voltage Electrophorator DW (10000 volts) either at pH 1.8 (formic acid-water, $20: 1000 \mathrm{v} / \mathrm{v}$ ) or at $\mathrm{pH} 6.4$ (acetic acid-collidine- $\mathrm{H}_{2} \mathrm{O}, 2.7: 6.6: 1000, \mathrm{v} / \mathrm{v} / \mathrm{v}$ ). The migrations of the compounds are given in Table 3 The elctrophoretograms were scanned and the radioactive spots were counted as described previously [10]. The various enzyme activities were compared by reference to the DD-carboxypeptidase activity. As defined previously [10], one DD-carboxypeptidase unit $(1 \mathrm{U})$ released one $\mu \mathrm{mol} \mathrm{D}$-alanine per min when the nucleotide UDP- $N$-acetylmuramyl-pentapeptide $(1.2 \mathrm{mM})$ was exposed to the enzyme at $37^{\circ} \mathrm{C}(35 \mu l$, final volume).

\section{RESULTS}

\section{Endopeptidase Activity}

When $0.3 \mathrm{mM}$ radioactive bisdisaccharide peptide dimer was exposed for $2 \mathrm{~h}$ at $37^{\circ} \mathrm{C}$ to $28 \mu \mathrm{g}$ protein of Brij-36T membrane extract, $17 \%$ of the dimer was hydrolyzed to disaccharide peptide monomers, $N$-Acetylmuramyl-L-alanine amidase activity which would give rise to disaccharide-free peptide dimer and monomer was not detected under the conditions of the assay. In the course of the fractionation of the membrane extract (Table 1), the endopeptidase activity per DD-carboxypeptidase activity underwent alterations so that the final preparations $A$ and $B$ differed from each other considerably in this respect. At equivalent $\mathrm{DD}$-carboxypeptidase activity, $25 \%$ of the bisdisaccharide peptide dimer $(0.3 \mathrm{mM})$ was hydrolyzed into monomers by fraction $\mathrm{B}$ after $2 \mathrm{~h}$ incubation, and by fraction $\mathrm{A}$ after $16 \mathrm{~h}$ incubation (Fig. 1).

\section{Unnatural Model Transpeptidase}

It has been shown [10] that fractionation of the Brij-36T membrane extract caused a partial dissociation between the DD-carboxypeptidase activity and the unnatural model transpeptidase activity (as determined by measuring the transfer reaction between non-radioactive UDP- $N$-acetylmuramylpentapeptide and $\left.\left[{ }^{14} \mathrm{C}\right] \mathrm{glycine}\right)$. At equivalent $\mathrm{DD}$ carboxypeptidase activity, fraction $B$ required five times more glycine acceptor than fraction $\mathrm{A}$ in order to achieve the same amount of transpeptidation (Fig. 5 in [10]). The replacement of $\left[{ }^{14} \mathrm{C}\right]$ glycine in the above assay by $\mathrm{D}-\left[{ }^{14} \mathrm{C}\right]$ alanine led to the same conclusion, i.e. that fraction $\mathrm{A}$ had a higher unnatural model transpeptidase activity than fraction $B$, per equivalent DD-carboxypeptidase unit (Fig.2). D-Ala- 
Table 3. Migration of radioactive compounds by electrophoresis on Whatman $3 M M$ paper (60 V/cm)

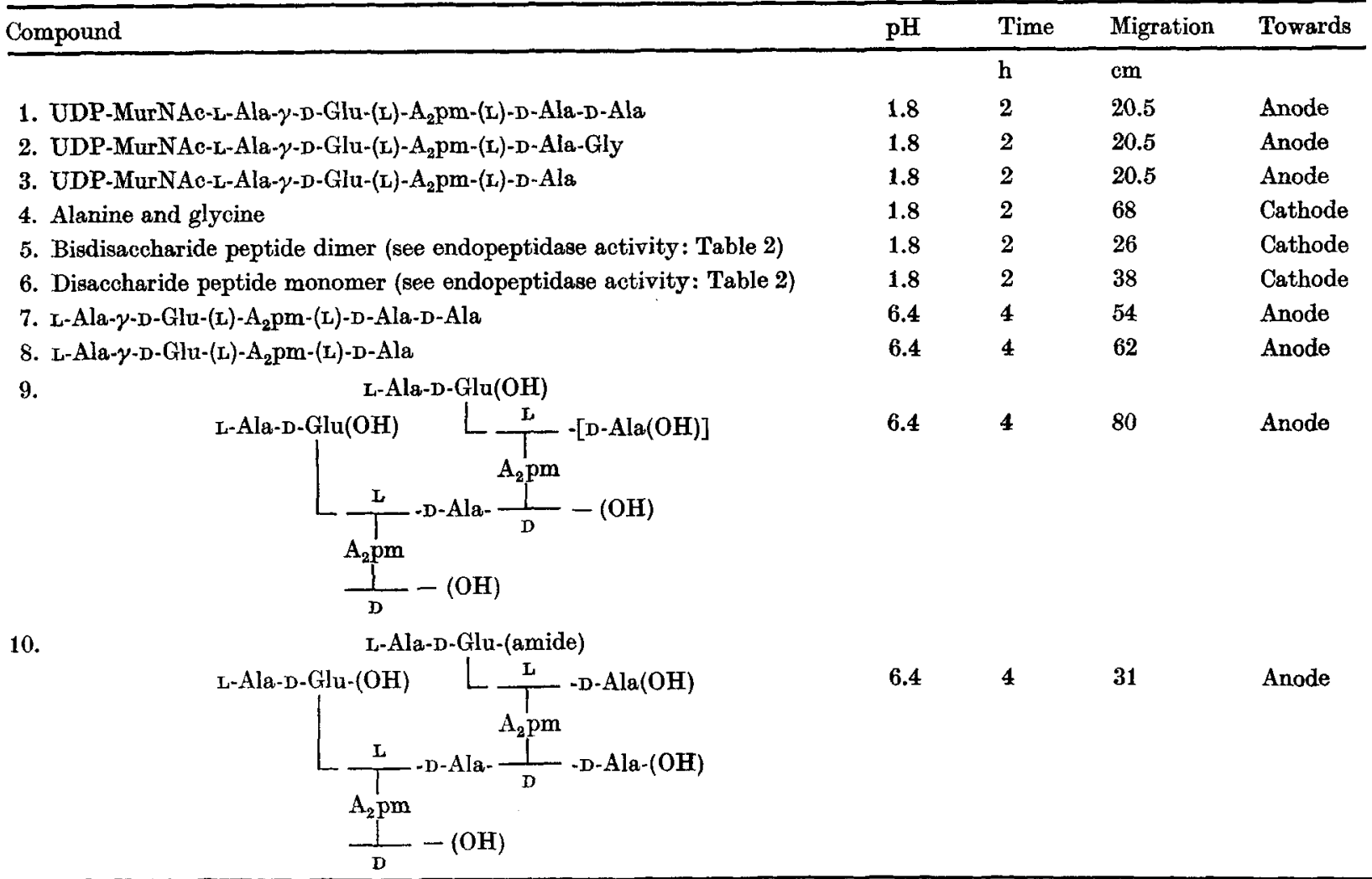

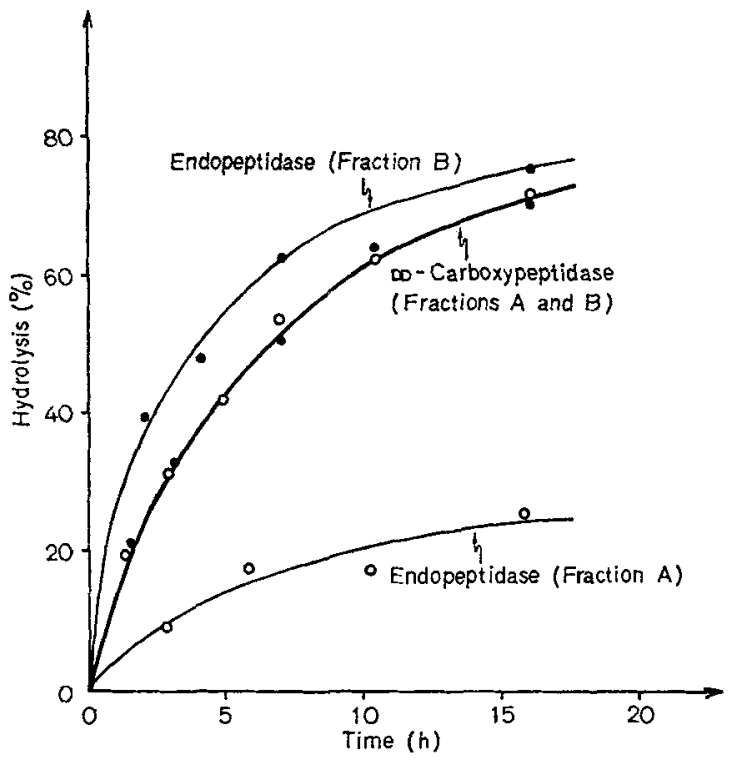

Fig. 1. DD-Carboxypeptidase activity $\nabla \mathrm{s}$ endopeptidase activity of fractions $A$ and $B$ : time course. Fractions $A$ and $B(120 \mu \mathrm{U})$ were incubated with UDP- $N$-acetylmuramyl-pentapeptide $(1.2 \mathrm{mM})$ for carboxypeptidase activity and with radioactive bisdisaccharide peptide dimer $(0.3 \mathrm{mM})$ for endopeptidase activity. Final reaction mixtures $(35 \mu l)$ were $0.06 \mathrm{M}$ Tris$\mathrm{HCl}$ buffer $\mathrm{pH} 8.5,0.05 \mathrm{M} \mathrm{MgCl}_{2}, 0.14 \mathrm{mM}$ dithiothreitol and $3-8 \%$ Brij-36T nine was a better acceptor than glycine and this property was true for both fractions $A$ and B. L-Alanine was not used as an acceptor (Fig. 2). It should be mentioned that when isolated membranes or Brij$36 \mathrm{~T}$ membrane extracts were used as enzyme sources, the transpeptidation assays with $\mathrm{D}-\left[{ }^{14} \mathrm{C}\right]$ alanine, instead of [ $\left.{ }^{14} \mathrm{C}\right]$ glycine, were unsuccessful. This failure is probably attributable to the fact that these preparations metabolized $\mathrm{D}-\left[{ }^{14} \mathrm{C}\right]$ alanine into several radioactive compounds which were separable by paper electrophoresis but were not identified. Enzymes metabolizing $\mathrm{D}$-alanine were also detected in $E$. coli K12 by Miyakawa et al. [15].

\section{Natural Model Transpeptidase Activity} with Radioactive Pentapeptide L-Alanyl- $\gamma$-D-glutamyl(L)-meso-diaminopimelyl-(L).D- ${ }^{14} C$ Jalanyl-D. [14C]alanine

The above pentapeptide is the one which is involved in peptide crosslinking during the biosynthesis of the wall peptidoglycan of $E$. coli (see Introduction). When this pentapeptide $(1.43 \mathrm{mM})$ was exposed to either fractions $A$ or $B$, concomitant bydrolysis (yielding the tetrapeptide no 8 in Table 3) and transfer (yielding the dimer no 9 in Table 3) occurred (Table 4). Fig.3 shows the separation by paper 
electrophoresis of the various radioactive compounds present in the reaction mixtures, i.e. free $\mathbf{D}$-alanine, tetrapeptide, dimer and residual pentapeptide. The peptide dimer formed under these conditions had the same migration as the peptide dimer either isolated through enzymic degradation of the $E$.coli wall peptidoglycan (Materials and Methods) or synthesized in vitro from the same pentapeptide through the action of the DD-carboxypeptidase-transpeptidase from Streptomyces R39 [16]. Under the conditions used (where less than $50 \%$ of the pentapeptide was utilized for hydrolysis and transpeptidation altogether) and within experimental error, the ratio of transpeptidation to hydrolysis of the pentapeptide was lower and the yield of dimer formation was

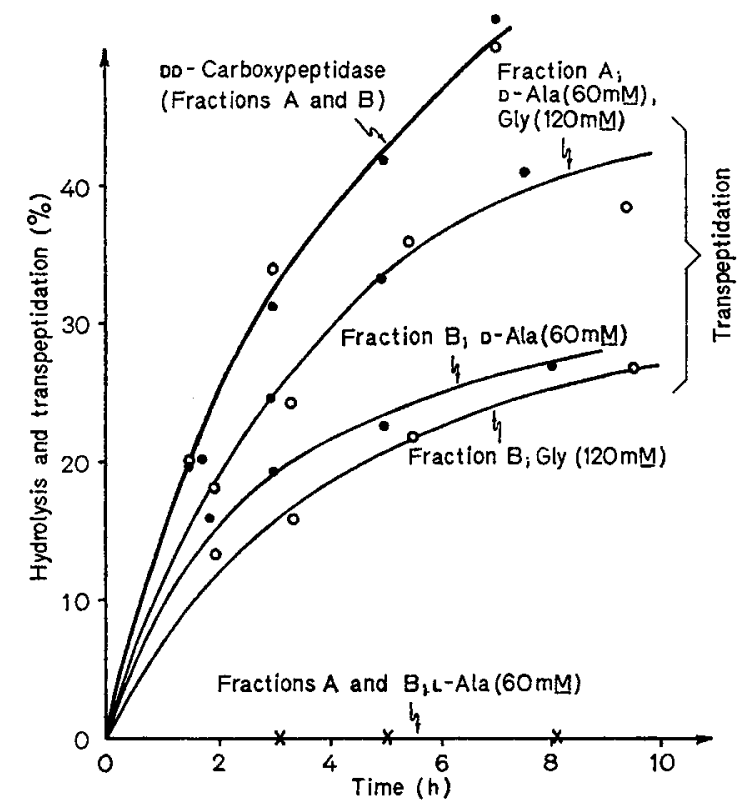

Fig. 2. Unnatural model transpeptidase activity of fractions $A$ and $B$ with $D$ - ${ }^{14} C$ ]alanine, $L-\Gamma^{14} C$ lalanine and ${ }^{14} C$ ]glycine as acceptors: time course. Fractions $A$ and $B(120 \mu \mathrm{U})$ were incubated under the same conditions as those described in Fig. 1 with non radioactive UDP- $N$-acetylmuramyl-pentapeptide $(1.2 \mathrm{mM})$ in the absence of amino acid acceptor (carboxypeptidase assay) and in the presence of (O) $120 \mathrm{mM}$ $\left[{ }^{14} \mathrm{C}\right]$ glycine, (e) $60 \mathrm{mM}$ D- $\left[{ }^{14} \mathrm{C}\right]$ alanine and $(X) 60 \mathrm{mM}$ L- $\left[{ }^{19} \mathrm{C}\right]$ alanine (transpeptidase assays) higher with fraction $B$ than with fraction $A$. When expressed in terms of the ratio of transpeptidation to hydrolysis, the efficiency of fraction $B$ in the natural model transpeptidation reaction was about 5 times higher than that of fraction $A$. In fact, the relative efficiency of fraction $B$ was probably underestimated since fraction $B$, when compared to fraction A, had a higher endopeptidase activity (Fig. 1) by virtue of which the dimer made by transpeptidation could be rehydrolyzed into monomers. The results shown in Table 4 were obtained with amounts of enzyme preparation corresponding to $120 \mu \mathrm{U}$ for fraction $\mathrm{A}$ and $40 \mu \mathrm{U}$ for fraction $\mathrm{B}$.

Based on these data, fraction B appeared to have, per DD-carboxypeptidase unit, a much higher natural model transpeptidase activity than fraction $A$, whereas the reverse was true for the unnatural model transpeptidase activity.

\section{Model Transpeptidase Activity}

with Radioactive Pentapeptide L-Alanyl- $\gamma-D$ glutamyl- $(L)$ meso-diaminopimelyl- $(L)-D-\left[{ }^{14} C\right] a l a n y l-$ $D-\left[{ }^{14} C\right.$ Jalanine and Non-Radioactive GlutamateAmidated Tetrapeptide L-Alanyl-D-isoglutaminyl-(L)meso-diaminopimelyl-(L)-D-alanine

The pentapeptide $L$-alanyl- $\gamma$-D-glutamyl-(L)-mesodiaminopimelyl-(L)-D-alanyl-D-alanine possesses both the donor group (the C-terminal D-alanyl-D-alanine) and the acceptor group (the free amino group located on the D-center of meso-diaminopimelic acid in $\alpha$-position to a free carboxyl group) required for transpeptidation reactions. The glutamate-amidated tetrapeptide L-alanyl-D-isoglutaminyl-(L)-meso-diaminopimelyl-(L)-D-alanine lacks the donor group but has the proper acceptor amino group. Hence, pentapeptide and glutamate-amidated tetrapeptide when exposed simultaneously to an active preparation, should compete for the same acceptor site on the enzyme. Moreover, in the presence of large amounts of glutamate-amidated tetrapeptide, the pentapeptide should lose its bifunctional property, being utilized under these conditions, exclusively as peptide donor. In these experiments, a glutamateamidated tetrapeptide was used instead of the nonamidated tetrapeptide which could be readily obtain-
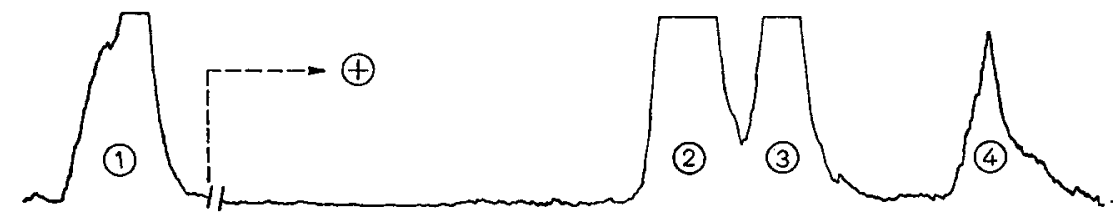

Fig. 3. Separation of radioactive compounds by paper electrophoresis at $\mathrm{pH} 6.5(4 h ; 60 \mathrm{~V} / \mathrm{cm})$. Mixture of, from left to right, (1) $D-\left[{ }^{14} \mathrm{C}\right]$ alanine (product of total reaction: hydrolysis + transpeptidation); (2) residual pentapeptide $\mathrm{L}$-alanyl$\gamma$-D-glutamyl - (L) -meso-diaminopimelyl - (L) -D-[14C]alanyl - D-
[14C]alanine; (3) tetrapeptide L-analyl- $\gamma$-D-glutamyl-(L)-meso-

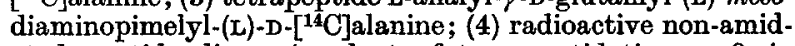
ated peptide dimer (product of transpeptidation no 9 in Table 3). For details, see text and legend of Table 3 
Table 4. Concomitant hydrolysis and transfer reactions with pentapeptide L-alanyl- $\gamma$-D-glutamyl-(L)-meso-diaminopimelyl-(L)-D$\left.{ }^{14} C\right]$ alanyl-D- $\left.{ }^{14} C\right]$ alanine by fractions $A$ and $B$

Radioactive pentapeptide $(1.5 \mathrm{mM})$ was incubated at $37^{\circ} \mathrm{C}$ with fraction $\mathrm{A}(120 \mu \mathrm{U})$ and fraction $\mathrm{B}$ (40 $\left.\mu \mathrm{U}\right)$. For composition of the reaction mixtures ( $35 \mu \mathrm{l}$, final volume), see Materials and Methods. Brij-36T concentration was 5-8\%. Yields are in percentages pentapeptide converted. It is not known whether this dimer (peptide no 9) which originates through dimerisation of the radioactive pentapeptide has one or two radioactive $D$-alanine residues since the $\mathrm{C}$-terminal $\mathrm{D}$ - $\left[{ }^{14} \mathrm{C}\right]$ alanine in the peptide dimer might be removed by carboxypeptidase action. The yield of conversion was calculated by multiplying the percentage of radioactivity found in the isolated peptide dimer by a factor of $\mathbf{1 . 5}$

\begin{tabular}{lllll}
\hline $\begin{array}{l}\text { Enzyme } \\
\text { fraction }\end{array}$ & $\begin{array}{l}\text { Time of incuba- } \\
\text { tion }\end{array}$ & $\begin{array}{l}\text { Yields from } \\
\text { Hydrolysis (tetrapeptide) }\end{array}$ & $\begin{array}{l}\text { Transpeptidation } \\
\text { (peptide no 9, Table 3) }\end{array}$ & $\begin{array}{l}\text { Ratio of transpepti- } \\
\text { dation to hydrolysis }\end{array}$ \\
\hline & h & $\%$ & & 0.07 \\
A & 2 & 19 & 1.3 & 0.05 \\
& 4 & 41 & 2 & 0.07 \\
\hline B & 8 & 36 & 4.9 & 0.32 \\
\end{tabular}

Table 5. Concomitant hydrolysis and transfer reactions occurring when radioactive pentapeptide L-alanyl- $\gamma$-D-glutamyl-( $L)$-mesodiaminopimelyl-(L)-D-[ $\left[{ }^{14} C\right]$ alanyl-D- $\left[{ }^{14} C\right]$ alanine and non-radioactive Glu-amidated tetrapeptide L-alanyl-D-isoglutaminyl- $(L)-$ meso-diaminopimelyl-(L)-D-alanine are simultaneously exposed to fractions $A^{\prime}$ and $B^{\prime}$

Radioactive pentapeptide $(1.5 \mathrm{mM}$ ) and increasing amounts of non-radioactive Glu-amidated tetrapeptide (from 0 to $75 \mathrm{mM}$ ) were incubated at $37^{\circ} \mathrm{C}$ with fraction $A^{\prime}\left(12 \times 10^{-5}\right.$ DD-carboxypeptidase units, $\left.8 \mathrm{~h}\right)$ and fraction $\mathrm{B}^{\prime}\left(24 \times 10^{-5} \mathrm{DD}^{-\mathrm{carboxy}}\right.$ peptidase units, $2 \mathrm{~h}$ ). For composition of the reaction mixtures (35 $\mu$, final volume), see Materials and Methods. Brij-36T concentration was $5-8 \%$ (final concentration). See Table 4 about the peptide dimer

\begin{tabular}{|c|c|c|c|c|c|c|c|}
\hline \multirow{3}{*}{$\begin{array}{l}\text { Enzyme } \\
\text { frection }\end{array}$} & \multirow{3}{*}{$\begin{array}{l}\text { Glu- } \\
\text { amidated } \\
\text { tetrapeptide }\end{array}$} & \multicolumn{3}{|l|}{ Yields } & \multicolumn{3}{|c|}{ Ratio of transpeptidation to hydrolysis } \\
\hline & & \multirow{2}{*}{$\begin{array}{l}\text { Hydrolysis } \\
\text { (tetrapep- } \\
\text { tide) }\end{array}$} & \multicolumn{2}{|c|}{ Transpeptidation } & \multirow{2}{*}{$\begin{array}{l}\text { Non-amidated } \\
\text { dimer to } \\
\text { tetrapeptide }\end{array}$} & \multirow{2}{*}{$\begin{array}{l}\text { Mono-amidated } \\
\text { dimer to } \\
\text { tetrapeptide }\end{array}$} & \multirow{2}{*}{$\begin{array}{l}\text { Total dimers } \\
\text { to tetra- } \\
\text { peptide }\end{array}$} \\
\hline & & & $\begin{array}{l}\text { Non-amidated } \\
\text { peptide dimer } \\
\text { (no 9, Table 3) }\end{array}$ & $\begin{array}{l}\text { Mono-amidated } \\
\text { peptide dimer } \\
\text { (no 10, Table 4) }\end{array}$ & & & \\
\hline & $\mathrm{mM}$ & $\%$ & & & & & \\
\hline $\mathbf{A}^{\prime}$ & $\begin{array}{l}0 \\
1.5 \\
15 \\
30 \\
75\end{array}$ & $\begin{array}{l}36.7 \\
29 \\
21 \\
18 \\
15\end{array}$ & $\begin{array}{l}2.7 \\
2.1 \\
1.2 \\
0.9 \\
0.8\end{array}$ & $\begin{array}{l}0 \\
1.3 \\
2.1 \\
3.2 \\
2.9\end{array}$ & $\begin{array}{l}0.075 \\
0.07 \\
0.06 \\
0.05 \\
0.05\end{array}$ & $\begin{array}{l}\overline{0.045} \\
0.1 \\
0.18 \\
0.19\end{array}$ & $\begin{array}{l}0.075 \\
0.115 \\
0.16 \\
0.23 \\
0.24\end{array}$ \\
\hline$B^{\prime}$ & $\begin{array}{r}0 \\
15 \\
30\end{array}$ & $\begin{array}{l}27 \\
13 \\
10\end{array}$ & $\begin{array}{l}6 \\
2.2 \\
1.5\end{array}$ & $\begin{array}{r}0 \\
11 \\
11\end{array}$ & $\begin{array}{l}0.23 \\
0.17 \\
0.15\end{array}$ & $\begin{array}{l}\overline{0.84} \\
1.10\end{array}$ & $\begin{array}{l}0.23 \\
1.01 \\
1.25\end{array}$ \\
\hline
\end{tabular}

ed by carboxypeptidase action on the free pentapeptide. Indeed, the presence of an amide group on the $\alpha$-carboxyl group of D-glutamic acid made it possible to separate the non-amidated peptide dimer (formed by dimerisation between two non-amidated pentapeptides; dimer no 9 in Table 3 ) from the monoamidated peptide dimer (formed by dimerisation between one non-amidated pentapeptide and one amidated tetrapeptide; dimer no 10 in Table 3). Fixed amounts of radioactive pentapeptide $(1.5 \mathrm{mM})$ were exposed to the enzyme preparation in the presence of increasing amounts of glutamate-amidated tetrapeptide (up to $75 \mathrm{mM}$ ). The experimental conditions were such that in the absence of glutamateamidated tetrapeptide, about $30-40 \%$ of the penta. peptide was utilized for the transpeptidation and the hydrolysis reactions altogether. The presence of increasing amounts of the glutamate-amidated tetrapeptide in the reaction mixtures had the three following effects (Table 5): (a) increasing amounts of mono-amidated peptide dimer were formed at the expense of the non-amidated peptide dimer, (b) the hydrolysis of the pentapeptide was inhibited and (c) the observed decrease in hydrolytic activity was greater than could be accounted for by the yield of the transpeptidation reactions, thus resulting in a 
progressive increase of the ratios of transpeptidation over bydrolysis. This property of the peptide acceptor to inhibit the hydrolysis of the peptide donor was a feature of the kinetics of concomitant transfer and hydrolysis reactions catalyzed by the single polypeptide DD-carboxypeptidase-transpeptidase enzymes excreted by Streptomyces R61 and R39 [12,17,18]. This similarity strongly suggested that a DD-carboxypeptidase-transpeptidase enzyme similar to the Streptomyces ones, occurred in $E$. coli and was present in both membrane fractions A and B. Finally, the data of Table 5 showed that, when expressed in terms of ratios of transpeptidation (i.e. formation of the hybrid mono-amidated peptide dimer) to hydrolysis, fraction $B$ was about 5 times more efficient than fraction $A$, i.e. a value which was identical to that obtained when fractions $A$ and $B$ were compared with respect to their natural model transpeptidase activity (Table 4).

\section{Effects of Glutamate-Amidated Tetrapeptide} on (a) Hydrolysis of Radioactive UDP-N-Acetyl. muramyl-pentapeptide (Carboxypeptidase Assay), (b) Hydrolysis of Bisdisaccharide Peptide Dimer into Disaccharide Peptide Monomer (Endopeptidase Assay) and (c) Transfer Reaction between UDP-N-Acetylmuramyl-pentapeptide and $\left[{ }^{14} \mathrm{C}\right]$ Glycine (Unnatural Model Transpeptidase Assay)

Since the glutamate-amidated tetrapeptide was recognized by the natural model DD-carboxypeptidase-transpeptidase (i.e. was an acceptor for the transpeptidation reaction and an inhibitor for the hydrolysis pathway of the pentapeptide donor), experiments were carried out in order to determine the possible inhibitory effects of the same glutamateamidated tetrapeptide on the other activities exhibited by the membrane fractions (endopeptidase, DD-carboxypeptidase and unnatural model transpeptidase). Radioactive bisdisaccharide peptide dimer $(0.33 \mathrm{mM}$; for endopeptidase assay), radioactive UDP- $N$-acetylmuramyl-pentapeptide $(1.5 \mathrm{mM}$; for carboxypeptidase assay) and non-radioactive UDP. $N$ acetylmuramyl-pentapeptide $(1.5 \mathrm{mM}$ supplemented with $7.5 \mathrm{mM}\left[{ }^{14} \mathrm{C}\right]$ glycine; for unnatural transpeptidase assay) were incubated with the preparation A $(120 \mu \mathrm{U})$ in the absence and in the presence of increasing concentrations of glutamate-amidated tetrapeptide (up to $77 \mathrm{mM}$ ). The scanning of the electrophoretograms did not reveal the presence of any peculiar radioactive compound which could have been produced by a transfer of the glutamateamidated tetrapeptide to the substrates used (transpeptidation with the bisdisaccharide peptide dimer would give rise to an hybrid mono-disaccharide mono-amidated peptide dimer; transpeptidation with UDP- $N$-acetylmuramyl-pentapeptide would

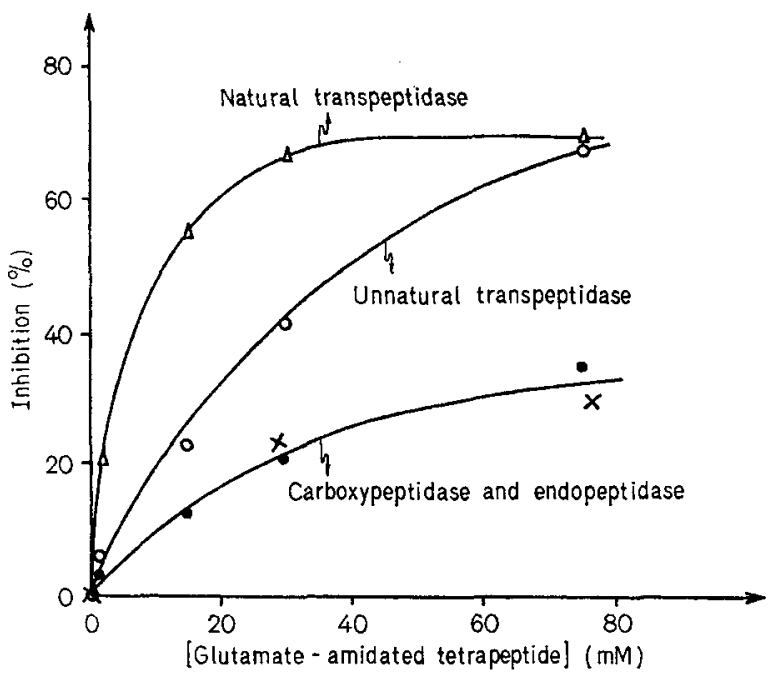

Fig.4. Effects of increasing concentrations of glutamateamidated tetrapeptide on the hydrolysis of radioactive UDP-Nacetylmuramyl-pentapeptide (carboxypeptidase assay), the hydrolysis of the radioactive bisdisaccharide peptide dimer (endopeptidase assay), the transfer reaction between non-radioactive $U D P$-N-acetylmuramyl-pentapeptide and $\left[{ }^{14} \mathrm{C}\right] g l y c i n e$ (unnatural model transpeptidase assay) and the transfer reaction between two radioactive pentapeptide units (natural model transpeptidase assay). Fraction A $(120 \mu \mathrm{U}$ per $35 \mu \mathrm{l})$, final volume) was used. For composition of the reaction mixtures, see Materials and Methods. Concentration of Brij-36T was $5-8 \%$ (final concentration). For the concentrations of the substrates, see text. Under the experimental conditions used and in the absence of glutamate-amidated tetrapeptide, the yields of hydrolysis were $32 \%$ in the carboxypeptidase assay and $17 \%$ in the endopeptidase assay. The yield of unnatural model transpeptidase (expressed in terms of UDP. $\mathrm{N}$-acetylmuramyl-pentapeptide converted into radioactive nucleotide) was $4.5 \%$ and the yield of natural model transpeptidase (expressed in terms of radioactive pentapeptide converted into radioactive non-amidated peptide dimer) was $2.7 \%$ (see Table 5)

give rise to an hybrid mono-amidated UDP- $N$-acetylmuramyl-octapeptide). Nevertheless, a partial inhibition of the endopeptidase, carboxypeptidase and unnatural model transpeptidase occurred (Fig.4). However, the decrease observed with the unnatural model transpeptidase was considerably higher than those observed with both the carboxypeptidase and the endopeptidase. The results suggested that a high proportion $(60-70 \%)$ of these two latter activities might occur in a form (or forms) that would not recognize the glutamate-amidated tetrapeptide and, consequently, would not be affected by its presence in the reaction mixture. The effect of glutamate-amidated tetrapeptide on the unnatural model transpeptidase was also compared with the effect of the same compound on the natural model transpeptidase (i.e. on the dimerisation between two pentapeptides L-alanyl- $\gamma$-D-glutamyl-(L)-meso-diaminopimelyl-(L)-D-alanyl-D-alanine; Table 5). At low 
concentrations, the glutamate-amidated tetrapeptide was a much more potent inhibitor of the natural model transpeptidase (Fig. 4). Interestingly, however, at high concentrations of glutamate-amidated tetrapeptide $(70 \mathrm{mM})$, both unnatural and natural model transpeptidase were inhibited to the same extent $(70 \%$, Fig. 4$)$.

\section{Influence of the Ampicillin-Affinose Treatment on the Fractionation of the $\mathbf{E}$. coli Enzyme Activities}

The partition of the various activities between fraction $\mathrm{A}^{\prime}$ and $\mathrm{B}^{\prime}$, i.e. before treatment with ampicillin-affinose (Table 1), was virtually identical to that found between fractions $A$ and $B$ that were either filtered through the ampicillin-affinose column or fixed on and eluted from it, respectively. Hence, the chromatography on DEAE-cellulose was the essential step of the fractionation procedure responsible for the observed distribution of the activities studied.

\section{DISCUSSION}

$E$. coli K12, strain 44, contains an enzyme system which, operationally, can be defined as follows. When acting on the pentapeptide L-alanyl- $\gamma$. D-glutamyl- (L) - meso-diaminopimelyl- (L) -D-alanyl-Dalanine, it catalyzes a transfer reaction leading to the formation of a peptide dimer (natural model transpeptidase), concomitantly with the hydrolysis of the pentapeptide into tetrapeptide. The glutamateamidated tetrapeptide L-alanyl-D-isoglutaminyl-(L)meso-diaminopimelyl-(L)-D-alanine which has the proper amino group for transpeptidation, acts as a competitor of the pentapeptide for the acceptor site on the enzyme system, causes the formation of an hybrid mono-amidated peptide dimer and decreases the extent of hydrolysis of the pentapeptide donor. Such activities can be attributed to a DD-carboxypeptidase-transpeptidase enzyme analogous to the purified DD-carboxypeptidase-transpeptidase single polypeptide enzymes isolated from the the culture filtrates of Streptomyces R39 and R61 [12,17,18]. This interpretation, if verified by the actual isolation and purification of the $E$. coli DD-carboxypeptidasetranspeptidase system, would support the concept of the ubiquitous occurrence of such a system among the bacteria. By virtue of their carboxypeptidase activity, the Streptomyces R39 and R61 DD-carboxypeptidase-transpeptidase enzymes also catalyze the liberation of the $\mathrm{C}$-terminal $\mathrm{D}$-alanine residue from the UDP- $N$-acetylmuramyl-pentapeptide and, although with a weak efficiency, the hydrolysis of peptide dimers into monomers $[19,20]$. Hence, it seems reasonable to assume that the $E$. coli DD-carboxypeptidase-transpeptidase system is also able to perform such activities and, more precisely, to propose that it is responsible for that part of the total hydrolytic (carboxypeptidase and endopeptidase) activity which can be inhibited by the glutamate-amidated tetrapeptide.

The fact that the unnatural model transpeptidase which catalyzes the replacement of $D$-alanine by glycine at the C-terminal position of the UDP- $N$ acetylmuramyl-pentapeptide is inhibited by high concentrations of the glutamate-amidated tetrapeptide, strongly suggests that this activity is also attributable to the DD-carboxypeptidase-transpeptidase system, However, fraction A has predominantly the unnatural model transpeptidase activtiy whereas fraction $B$ has predominantly the natural model transpeptidase activity. It is possible that one is dealing with distinct $\mathrm{DD}$-carboxypeptidase-transpeptidase proteins that are characterized by specific differences in their relationships between binding and/or catalytically active sites. Another possibility is that $E$. coli possesses one single DDcarboxypeptidase-transpeptidase enzyme protein but that differences in the microenvironment of fraction $A / A^{\prime}$ and fraction $B / B^{\prime}$ (either naturally preexisting in the membranes or artificially created by the fractionation procedure) would alter the functioning of the enzyme. The fact that the proportion of the activity of the Streptomyces enzymes that can be channelled into the transpeptidation or the hydrolysis pathways depends upon the environmental conditions $[12,17,18]$ is consistent with this latter interpretation.

A high proportion of the DD-carboxypeptidase and endopeptidase activities in $E$. coli K12, strain 44, appears not to be affected by the glutamate-amidated tetrapeptide and, for this reason, is probably catalyzed by an enzyme system which is distinct from the DD-carboxypeptidase-transpeptidase one(s). Fraction $A$ has predominantly the carboxypeptidase activity and fraction $B$ has predominantly the endopeptidase activity. Again, these two activities might be catalyzed either by distinct proteins or by one single protein of which the functioning would depend upon the microenvironmental conditions.

The composition of the $E$. coli "DD-carboxypeptidase-transpeptidase-endopeptidase" complex, as revealed by the present studies, is summarized in Table 6. Relative to DD-carboxypeptidase activity, fraction $B$ (or $B^{\prime}$ ) had predominantly the natural model transpeptidase (and low unnatural model transpeptidase and endopeptidase activities) whereas the contrary was true for fraction $A$. The fact that partition of the enzyme activities was not clear-cut seemingly indicated that an appreciable extent of cross-contamination occurred between the two fractions. However, the fractions were not cross-contaminated, as demonstrated in the following paper [13], where the inhibitory action of cephalothin and ampicillin was used as a probe for further characterization of the enzyme activities. 
Table 6. The DD-carboxypeptidase-transpeptidase-endopeptidase complex in Escherichia coli K12, strain 44 See Table 2 about activity

\begin{tabular}{|c|c|c|c|}
\hline System & Activity & $\begin{array}{l}\text { Action of glutamate- } \\
\text { amidated tetrapeptide }\end{array}$ & Enzymes involved \\
\hline \multirow[t]{3}{*}{$\begin{array}{l}\text { DD-Carboxypeptidase- } \\
\text { transpeptidase system }\end{array}$} & Natural transpeptidase $(++)$ & $\begin{array}{l}\text { Acceptor } \rightarrow \text { hybrid dimer and } \\
\text { Inhibitor of the hydrolysis } \\
\text { pathway }\end{array}$ & \multirow[t]{3}{*}{$\begin{array}{l}\text { Distinct enzyme proteins or } \\
\text { one enzyme protein occurring } \\
\text { in different active forms }\end{array}$} \\
\hline & Unnatural transpeptidase $(++)$ & $\begin{array}{l}\text { Acceptor function (?): } \\
\text { not detected Inhibitor }\end{array}$ & \\
\hline & $\begin{array}{l}\text { Do-Carboxypeptidase }( \pm) \\
\text { Endopeptidase }( \pm)\end{array}$ & $\begin{array}{l}\text { Inhibitor } \\
\text { Inhibitor }\end{array}$ & \\
\hline \multirow[t]{2}{*}{$\begin{array}{l}\text { DD-Carboxypeptidase- } \\
\text { endopeptidase system }\end{array}$} & $\begin{array}{l}\text { DD-Carboxypeptidase }(++) \\
\text { and endopeptidase }( \pm)\end{array}$ & No effect & \multirow{2}{*}{$\begin{array}{l}\text { Distinct enzyme proteins or } \\
\text { one enzyme protein occurring } \\
\text { in different active forms }\end{array}$} \\
\hline & $\begin{array}{l}\text { Endopeptidase }(++) \text { and } \\
\text { DD-carboxypeptidase }( \pm)\end{array}$ & No effect & \\
\hline
\end{tabular}

Grants from the Fonds de la Recherche Fondamentale Collective, Brussels (No. 515 and 1000) and the Institut pour l'Encouragement de la Recherche Scientifique dans l'Industrie et l'Agriculture, Brussels (No. 1699 and 2013) are gratefully acknowledged. This work was also supported by grants from the National Science Foundation (No. GB 17107) to M. R. J. Salton and from the National Institutes of Allergy and Infectious Diseases (no AI 11489) to J. J. Pollock. This paper is from a dissertation submitted by M. N.-D. in partial fulfilment of the requirements for a Ph.D. degree, University of Liège (1973).

\section{REFERENCES}

1. Izaki, K., Matsuhashi, M. \& Strominger, J. L. (1966) Biochemistry, 55, 656-663.

2. Izaki, K., Matsuhashi, M. \& Strominger, J. L. (1968) J. Biol. Chem. 243, 3180-3192.

3. Izaki, K. \& Strominger, J. L. (1968) J. Biol. Chem. 243, $3193-3201$.

4. Araki, V., Shimada, A. T. \& Ito, E. (1966) Biochem. Biophys. Res. Commun. 23, 518-525.

5. Araki, Y., Shirai, R., Shimada, A., Ishimoto, N. \& Ito, E. (1966) Biochem. Biophys. Res. Commun. 23, 466472 .

6. Pelzer, H. von (1963) Z. Naturforsch. Teil 18B, 11, $950-956$.

7. Pelzer, H. von (1963) Z. Naturforsch. Teil 18B, 11, 957-964.

8. Bogdanovsky, D., Bricas, E. \& Dezélée, Ph. (1969) C. R. Hebd. Séances Acad. Sci. (Paris) 269, 390-393.
9. Van Heijenoort, J., Elbaz, L., Dezélée, Ph., Petit, J. F., Bricas, E. \& Ghuysen, J. M. (1969) Biochemistry, 8, $207-213$.

10. Pollock, J. J., Nguyen-Distèche, M., Ghuysen, J. M., Coyette, J., Linder, R., Salton, M. R. J., Kim, K. S., Perkins, H. R. a\& Reynolds, P. (1974) Eur. J. Biochem. 41, $439-446$.

11. Ghuysen, J. M. (1968) Bacteriol. Rev. 32, 425-464.

12. Ghuysen, J. M., Leyh-Bouille, M., Campbell, J. N. Moreno, R., Frère, J. M., Duez, C., Nieto, M. \& Perkins, H. R. (1973) Biochemistry, 12, 1243-1251.

13. Nguyen-Distèche, M., Pollock, J. J., Ghuysen, J. M., Puig, J., Reynolds, P., Perkins, H. R., Coyette, J. \& Salton, M. J. R. (1974) Eur. J. Biochem. 41, 457-463.

14. Braun, V. \& Rehn, K. (1969) Eur. J. Biochem. 10, $426-438$.

15. Miyakawa, T., Matsujawa, H., Matsuhashi, M. \& Sugino, Y. (1972) J. Bacteriol. 112, 950-958.

16. Ghuysen, J. M., Leyh-Bouille, M., Frère, J. M., Dusart, J., Marquet, A., Perkins, H. R. \& Nieto, M. (1974) Ann. N.Y. Acad. Sci. (in press).

17. Perkins, H. R., Nieto, M., Frère, J. M., Leyh-Bouille, M. \& Ghuysen, J. M. (1973) Biochem. J. 131, 707-718.

18. Frère, J. M., Ghuysen, J. M., Perkins, H. R. \& Nieto, M. (1973) Biochem. J. 135, 463-468.

19. Leyh-Bouille, M., Coyette, J., Ghuysen, J. M., Idczak, J., Perkins, H. R. \& Nieto, M. (1971) Biochemistry, 10, $2163-2170$.

20. Leyh-Bouille, M., Nakel, M., Frère, J. M., Johnson, K., Ghuysen, J. M., Nieto, M. \& Perkins, H. R. (1972) Biochemistry, 11, 1290-1298.

M. Nguyen-Distèche, J.-M. Ghuysen, and J. Coyette, Institut de Botanique, Université de Liège au Sart-Tilman, B-4000 par Liège 1, Belgium

J. J. Pollock's present address: Department of Oral Biology and Pathology, State University of New York at Stony Brook, Stony Brook, New York, U.S.A. 11790

P. Reynolds, Department of Biochemistry University of Cambridge, Tennis Court Road, Cambridge, Great Britain, CB2 1QW

H. R. Perkins, M. R. C. National Institute for Medical Research, The Ridgeway, Mill Hill, London, Great Britain, NW7 1AA

M. R. J. Salton, Department of Microbiology, New York University School of Medicine, 550 First Avenue, New York City, New York, U.S.A. 10016 